\title{
S100 calcium binding proteins and ion channels
}

\author{
Anton Hermann ${ }^{1}{ }^{*}$, Rosario Donato ${ }^{2}$,Thomas M. Weiger ${ }^{1}$ and Walter J. Chazin ${ }^{3}$ \\ 1 Division of Cellular and Molecular Neurobiology, Department of Cell Biology, University of Salzburg, Salzburg, Austria \\ ${ }^{2}$ Department of Experimental Medicine and Biochemical Sciences, University of Perugia, Perugia, Italy \\ ${ }^{3}$ Departments of Biochemistry and Chemistry, Center for Structural Biology, Vanderbilt University, Nashville, TN, USA
}

Edited by:

Amalia M. Dolga, Philipps-Universität Marburg, Germany

Reviewed by:

Jason B. Wu, Cedars-Sinai Medical Center, USA

Estelle Leclerc, North Dakota State University, USA

Raghunatha Yammani, Wake Forest

School of Medicine, USA

${ }^{*}$ Correspondence:

Anton Hermann, Division Cellular and Molecular Neurobiology, Department Cell Biology, University of Salzburg, Hellbrunnerstr. 34, A-5020 Salzburg, Austria.

e-mail:anton.hermann@sbg.ac.at
S100 $\mathrm{Ca}^{2+}$-binding proteins have been associated with a multitude of intracellular $\mathrm{Ca}^{2+}$ dependent functions including regulation of the cell cycle, cell differentiation, cell motility and apoptosis, modulation of membrane-cytoskeletal interactions, transduction of intracellular $\mathrm{Ca}^{2+}$ signals, and in mediating learning and memory. S100 proteins are fine tuned to read the intracellular free $\mathrm{Ca}^{2+}$ concentration and affect protein phosphorylation, which makes them candidates to modulate certain ion channels and neuronal electrical behavior. Certain S100s are secreted from cells and are found in extracellular fluids where they exert unique extracellular functions. In addition to their neurotrophic activity, some S100 proteins modulate neuronal electrical discharge activity and appear to act directly on ion channels. The first reports regarding these effects suggested S100-mediated alterations in $\mathrm{Ca}^{2+}$ fluxes, $\mathrm{K}^{+}$currents, and neuronal discharge activity. Recent reports revealed direct and indirect interactions with $\mathrm{Ca}^{2+}, \mathrm{K}^{+}, \mathrm{Cl}^{-}$, and ligand activated channels. This review focuses on studies of the physical and functional interactions of S100 proteins and ion channels.

Keywords: S100, calcium binding protein, ion channel, EF-hand

\section{ION CHANNELS}

Ion channel proteins form hydrophilic pores integrated into lipid bilayer membranes allowing the passage of ions into and out of cells. Channels are incorporated not only in the plasma membrane, but also in membranes of intracellular organelles, including the endoplasmic reticulum, nuclear membrane, and mitochondria. Ion channels are found early in the evolution of life and are essential for the function of cells in every organism from bacteria, protozoa, and plants, to animals. Their functions range from the

\footnotetext{
Abbreviations: 5-HT, serotonin receptor; AMPA, $\alpha$-amino-3-hydroxy-5-methyl-4isoxazolepropionic acid receptor; ASIC, acid-sensing ion channels; BK, big or large conductance calcium activated $\mathrm{K}^{+}$channels; $\mathrm{Ca}^{2+}$, calcium ion; CaBP, calcium binding protein; cAMP/PKA/CnA, cyclic adenosine monophosphate/protein kinase $\mathrm{A} /$ calcineurin $\mathrm{A}$ - protein phosphatase; CFTR, cystic fibrosis transmembrane conductance; cGMP, cyclic guanosine monophosphate; C-terminal, carboxy terminus of proteins; $\mathrm{Cl}^{-}$, chloride ion; D3-D4, linker between domains 3 and 4 (channel); EF-hand, helix-loop-helix structural motif of calcium binding proteins; EK, potassium equilibrium potential; hEAG, human ether a go-go $\mathrm{K}^{+}$channel; IK, calcium activated intermediate conductance $\mathrm{K}^{+}$channels; IQ motif, proteins that contain IQ motifs typically bind calmodulin in the absence of $\mathrm{Ca}^{2+} ; \mathrm{K}^{+}$, potassium ion; $\mathrm{K}_{2 \mathrm{P}}$, two-pore domain $\mathrm{K}^{+}$channel; $\mathrm{K}_{\mathrm{ir}}$, inward rectifier $\mathrm{K}^{+}$channel; $\mathrm{K}_{\mathrm{v}}$, voltage gated $\mathrm{K}^{+}$channel; KRR, lysine- arginine-arginine; L-type $\mathrm{Ca}^{2+}$ channel, voltage gated $\mathrm{Ca}^{2+}$ channel with large conductance and long-lasting activation; MAPK, mitogenactivated protein kinase; $\mathrm{Mn}^{2+}$, manganese ion; $\mathrm{Na}^{+}$, sodium ion; $\mathrm{Na}_{\mathrm{v}}$, voltage gated $\mathrm{Na}^{+}$channel; NMDA, $\mathrm{N}$-methyl-D-aspartate; $\mathrm{N}$-terminal, amino-terminus of proteins; p11, S100A10 protein; PKA, protein kinase A; pS, piko Siemens; RAGE, receptor for advanced glycation end products; ROS-GC, rod outer segment guanylate cyclase; RyR, ryanodine receptor; S100, protein soluble in 100\% ammonium sulfate; S100B-s-s, disulfide linked form of S100B; S1-S6 TMS, transmembrane segments 1-6 (channel); SCG, superior cervical ganglion; SK, small conductance calcium activated $\mathrm{K}^{+}$channels; SR, sarcoplasmatic reticulum; SSV, serine-serinevaline; TASK, TWIK-related Acid Sensitive $\mathrm{K}^{+}$channel; TMS, transmembrane segments; T-tubulus, transverse tubulus (muscle); TRP, transient receptor potential; TTX, tetrodotoxin; $\mathrm{Zn}^{2+}$, zinc ion.
}

modulation of bioelectric processes, such as sensory transduction, action potential generation and propagation, and synaptic transmission, to muscle contraction and osmoregulation, control of hormone release, and cell cycle coordination (e.g., in Hille, 2001; Weiger et al., 2002). Many ion channels are highly selective for a certain type of ion, such as $\mathrm{K}^{+}, \mathrm{Na}^{+}, \mathrm{Ca}^{2+}$, or $\mathrm{Cl}^{-}$; others, like NMDA or AMPA receptors, are less selective and allow different cations to pass. An element known as the selectivity filter within the channel pore is the critical determinant of what type of ions can be transmitted by a channel.

Conformational changes between closed, open, and inactive states are termed channel gating. Since there are many channels within a membrane, the equilibrium between these conformational states determines the amount of current that flows across the membrane as a function of time. Importantly, channel gating is initiated by: (i) changes of the voltage across the membrane, (ii) binding of ligands such as neurotransmitters, hormones, intracellular messengers (e.g., $\mathrm{Ca}^{2+}$, cyclic nucleotides), (iii) mechanical stress to the protein or via the cytoskeleton linked to channels, or (iv) covalent modifications such as protein phosphorylation, carboxylation, or sulfuration (Levitan, 1999; Hermann et al., 2012). Ion channels can be blocked by chemical agents or by peptide toxins, which can be used for separation of ion currents or for identification of certain types of channels. Modifications to channel gating function can occur across a large range of timescales from milliseconds to hours or even days. Long-term changes of the electrical excitability of neurons may be considered as a kind of cellular memory.

Mutations at ion channels are involved in causing a number of diseases, including diabetes, epilepsy, heart failure, myotonia, and deafness (Shieh et al., 2000; Ashcroft, 2006; Bernard and Shevell, 
2008; Kullmann, 2010). Patch clamp techniques have proven as powerful means to study ion channels in action. Together with molecular biology techniques, in particular site-directed mutagenesis, it has become possible to investigate intimate details of channel structure and function, and the molecular basis for channel-associated diseases.

A number of ion channels are activated or modulated by intracellular $\mathrm{Ca}^{2+}$ signals giving rise to the notion that $\mathrm{Ca}^{2+}$ binding proteins $(\mathrm{CaBP})$ may play a role in regulating channel gating function. For example, CaBPs have been found to modulate neuronal electrical discharge activity (Celio, 1986; Kawaguchi et al., 1987; Barger and van Eldik, 1992; Hermann and Kerschbaum, 1994; Kubista et al., 1999; Burgoyne and Weiss, 2001; Schwaller, 2010). These effects are based on either alterations of intracellular $\mathrm{Ca}^{2+}$, which secondarily affects ion channels, transmitter release, and activation of second messengers, or on direct action of a CaBP on ion channels (i.e., in Neher and Sakaba, 2008; Nejatbakhsh and Feng, 2011). Some $\mathrm{K}^{+}, \mathrm{Na}^{+}$, and $\mathrm{Cl}^{-}$channels are regulated directly by intracellular $\mathrm{Ca}^{2+}$. Among these, $\mathrm{Ca}^{2+}$-activated $\mathrm{K}^{+}$ channels are prominent in this respect, as they are found in a wide variety of excitable and non-excitable cells and in many species. The most prominent of these CaBPs is the ubiquitous intracellular $\mathrm{Ca}^{2+}$ sensor calmodulin. $\mathrm{Ca}^{2+}$-dependent regulation of ion channels was reviewed 6 years ago (Shah et al., 2006a). Here, we focus on the relatively recent and growing evidence for roles played by the S100 proteins.

\section{S100 CALCIUM BINDING PROTEINS}

S100 proteins are a group of $>20 \mathrm{EF}$-hand $\mathrm{Ca}^{2+}$-binding proteins that are distinguished by several unique characteristics including expression in a cell-specific manner and functions in both intracellular and extracellular contexts (Donato, 2001; Heizmann, 2002; Chazin, 2011). The proteins appear to be exclusively expressed in vertebrates on the basis of genomic analyses, which points to specialized roles evolved late in evolution. These roles are believed to involve the refinement or fine tuning of cell-specific activities and/or responses. Of the 24 human S100 genes, 19, plus a number of S100A pseudogenes are located within chromosome 1q21. Other gene locations include S100A11P, which maps to chromosome 7q22-q3, S100B, which maps to chromosome 21q22, S100G, which maps to chromosome $X p 22, \mathrm{~S} 100 \mathrm{P}$, which maps to chromosome 4p16, and S100Z, which maps to chromosome 5q13 (Marenholz et al., 2004). S100 proteins are distinguished from other EF-hand proteins by the unique manner in which they bind $\mathrm{Ca}^{2+}$ ions in their N-terminal binding sites, a distinctive dimeric architecture, and the ability to bind transition metals such as zinc, copper, and manganese at histidine-rich binding sites at the dimer interface. The large number of atomic resolution structures determined for S100 proteins reveal a very common structure. Thus, they can be best classified on the basis of their functional roles (for overview of structure and function of S100 proteins see Donato, 2001, 2003; Heizmann, 2002; Chazin, 2011).

S100 proteins regulate a diverse array of cellular activities, including the cell cycle (Arcuri et al., 2005; Brozzi et al., 2009), cell differentiation and survival (Arcuri et al., 2005; Tsoporis et al., 2005; Rosenberger et al., 2007; Cheng et al., 2008; Tubaro et al., 2010; Beccafico et al., 2011; Liu et al., 2011; Riuzzi et al., 2011), apoptosis (van Dieck et al., 2009; Lin et al., 2010; Tubaro et al., 2011), cell motility (Brozzi et al., 2009; Chen et al., 2009), membrane-cytoskeleton interactions and cytoskeleton dynamics (Donato, 2001; Brozzi et al., 2009), intracellular $\mathrm{Ca}^{2+}$ homeostasis (Donato et al., 2009; Rohde et al., 2010), transduction of intracellular $\mathrm{Ca}^{2+}$ signals (Donato, 2001; Heizmann, 2002; Gilquin et al., 2010), learning and memory (Nishiyama et al., 2002), phototransduction (Pozdnyakov et al., 1997; Rambotti et al., 1999; Duda et al., 2002), adaptive responses to antidepressants (Svenningsson and Greengard, 2007; Rescher and Gerke, 2008; Baudry et al., 2010), and innate and adaptive immunity (Donato, 2001; Heizmann, 2002; Bode et al., 2008). They are also associated with a wide array of pathological conditions such as inflammation (Donato, 2001, 2007; Heizmann, 2002; Vogl et al., 2007; Cheng et al., 2008; Donato et al., 2009; Ehrchen et al., 2009; Hsu et al., 2009; Hofmann Bowman et al., 2010; Lim et al., 2010, 2011; Wolf et al., 2011a), cancer (Donato, 2001, 2007; Heizmann, 2002; Emberley et al., 2005; Stein et al., 2006; Ismail et al., 2008; Chen et al., 2009; Donato et al., 2009; Slomnicki et al., 2009; van Dieck et al., 2009; Lin et al., 2010; Malashkevich et al., 2010; Wolf et al., 2011b), diabetes and its complications (Eggers et al., 2011), atherosclerosis (Averill et al., 2011), mood and personality disorders (Steiner et al., 2010, 2011), and neurodegeneration (Donato, 2001, 2007; Heizmann, 2002; Donato et al., 2009; Sorci et al., 2010).

Most S100 proteins exert intracellular regulatory activities by interacting with specific target sites in a $\mathrm{Ca}^{2+}$-dependent manner (Donato, 2003; Bhattacharya et al., 2004; Donato et al., 2009; Zimmer and Weber, 2010). At low internal $\mathrm{Ca}^{2+}$ concentration, as in the resting state of cells, S100 proteins occupy a closed relatively hydrophilic conformation. During cell activation the intracellular $\mathrm{Ca}^{2+}$ concentration increases due to $\mathrm{Ca}^{2+}$ influx via plasma membrane $\mathrm{Ca}^{2+}$ channels or liberation from intracellular $\mathrm{Ca}^{2+}$ stores such as the endoplasmic or sarcoplasmatic reticulum (SR). $\mathrm{S} 100$ proteins have affinites for $\mathrm{Ca}^{2+}$ in a range that allows them to respond to these higher $\mathrm{Ca}^{2+}$ concentrations (with one exception of S100A10, which is $\mathrm{Ca}^{2+}$ insensitive). Binding of $\mathrm{Ca}^{2+}$ to S100s exposes hydrophobic sites, which enable them to interact with specific target proteins or membranes (Bhattacharya et al., 2004). A great variety of targets have been identified over the years, including enzymes, cytoskeletal constituents, transcription factors, scaffolding proteins, unsaturated fatty acids, channels, receptors, signaling molecules, and toll-like receptor ligands (Donato, 2003; Sorci et al., 2011). Thus, S100 proteins are extremely versatile and are able to perform functions in an array of cellular pathways.

Some S100 proteins can be secreted and have the potential to act on the external surface of plasma membranes. In contrast to intracellular function, extracellular S100 proteins will have all $\mathrm{Ca}^{2+}$ binding sites occupied so the molecular basis for their function is dependent on other properties, including their ability to oligomerize or to bind transition metals such as $\mathrm{Zn}^{2+}$ and $\mathrm{Mn}^{2+}$. Due to their hydrophobic nature in the $\mathrm{Ca}^{2+}$ loaded state, it is possible that $S 100$ proteins may directly interact with the lipid phase of the membrane (Curatola et al., 1985; Zolese et al., 1988) and perturbation of membrane lipids may affect membrane channel activity. Direct interactions of S100G with phospholipids have been been characterized (Malmendal et al., 2005). S100 proteins could also act at the extracellular face on membrane localized proteins such as 
receptors or ion channels. One such receptor is RAGE (receptor for advanced glycation end products), which is found in inflamed tissue and in several human cancers. RAGE binds and signals through a number of S100 proteins, including S100A1, S100A2, S100A5, S100A6, S100A7, S100A8/A9, S100A11, S100A12, S100A13, S100B, and S100P in a high number of cell types (Donato, 2007; Heizmann et al., 2007; Ghavami et al., 2008; Leclerc et al., 2009; Beccafico et al., 2011; Eggers et al., 2011). In addition, G-protein-coupled receptors, scavenger receptors, and toll-like receptor 4 transduce effects of certain S100 proteins (Vogl et al., 2007; Yan et al., 2008; Pietzsch and Hoppmann, 2009; Hoppmann et al., 2010). Lastly, S100A4 and S100B interact with epidermal growth factor ligands and basic fibroblast growth factor, respectively (Klingelhöfer et al., 2009; Riuzzi et al., 2011, 2012) thereby enhancing cognate receptor activity. External binding of S100 proteins to ion channels has, however, not been reported so far.

\section{S100 PROTEINS AND MODULATION OF ION CHANNELS}

The first reports relating to an S100 protein (likely S100B) modulating channel activity involved affects on discharge activity in mollusk neurons (Shtark et al., 1981; Nikitin et al., 1988). In particular, anti-S100 antiserum was found to inhibit electrical activity of these neurons and caused a reduction of both inward and outward currents (Pozdnyakova, 1988; Andrianov et al., 2003; Gainutdinov et al., 2006; Timoshenko et al., 2009). From these studies it was concluded that the S100-antigen is accessible to S100 antibodies and therefore is localized at the plasma membrane. S100 immunoreactivity was also found in protozoa, earthworms, crustacean, and insects (Michetti and Cocchia, 1982; Endo and Endo, 1988). In the snail (Helix pomatia) central nervous system, an S100 immunoreactive protein of $12-14 \mathrm{kDa}$, as revealed by Western blot analysis, was localized in a subpopulation of neurons (Kubista et al., 1996). These neurons are specified by their spontaneous discharge activity and a prominent $\mathrm{Ca}^{2+}$-activated $\mathrm{K}^{+}$outward current (Hermann et al., 1995). S100 immunoreactivity was present in neurons, but not in glial cells, endocrine cells, or in muscle, and its presence was correlated with spontaneous discharge activity of these cells. Extracellular S100B-s-s, a disulfide linked form of S100B, which is secreted and/or released from several mammalian cells (Donato et al., 2009) in nanogram quantities caused hyperpolarization of the membrane resting potential and inhibition of the spontaneous discharge activity of action potentials (Kubista et al., 1999). Furthermore, the stimulus-response property of neurons was found to be altered from tonic to phasic discharge, the duration of action potentials was decreased, their after hypolarization increased, and the membrane input resistance reduced. Voltage clamp experiments revealed that the total outward current was increased by S100B-s-s-. Detailed analysis of outward currents showed that three types of $\mathrm{K}^{+}$currents were altered: the inward rectifying current was increased by S100B-s-s- as was the $\mathrm{Ca}^{2+}$-activated $\mathrm{K}^{+}$outward current, whereas the delayed, voltage-dependent $\mathrm{K}^{+}$ current was decreased. The transient $\mathrm{K}^{+}$outward current and the $\mathrm{Ca}^{2+}$ inward current also present in these neurons were not affected by S100B-s-s-. Immunocytochemistry revealed that after extracellular application of S100B-s-s-, intracellular labeling of the cytoplasm revealed internalization. Injection of S100A1 mimicked the effects of S100B-s-s- on discharge activity and action potentials. From these experiments it was concluded that S100 may play a role as neuromodulator in nervous functions (Kubista et al., 1999). Although evidence is still missing that S100 proteins are present in invertebrates there are clear effects on electrical activity, which indicates that channel proteins interact with S100 and alter their conductive properties.

\section{S100s AND $\mathrm{Ca}^{2+}$ CHANNELS}

Recently, ion channels have been recognized as potential targets for S100 proteins. S100A1, for example, increases the L-type $\mathrm{Ca}^{2+}$ channel current in embryonic mouse and neonatal rat ventricular cardiomyocytes. Because protein kinase A (PKA) block abolished the S100A1 effect on $\mathrm{Ca}^{2+}$ channels it was concluded that a S100A1 mediated increase of PKA enhances $\mathrm{Ca}^{2+}$ influx (Reppel et al., 2005). Chronic deficiency of S100A1 in knock-out mice results in an elevated $\mathrm{Ca}^{2+}$ inward current but a blunted $\beta$-adrenergic response due to an impaired fractional $\mathrm{Ca}^{2+}$ release mechanism from intracellular stores (Gusev et al., 2009).

S100A10, also known as p11 or calpactinI light chain, is " $\mathrm{Ca}^{2+}$ insensitive" because of mutations within the $\mathrm{Ca}^{2+}$ binding loops of its EF-hands. The S100A10 molecular structure is equivalent to the $\mathrm{Ca}^{2+}$ bound forms of other $\mathrm{S} 100$ proteins with exposed hydrophobic sites which render the protein in a permanently active state. The protein associates with annexin 2 into a heterotetrameric complex and hence is able to specifically target membranes (Gerke and Moss, 2002; Rescher and Gerke, 2008). $\mathrm{Ca}^{2+}$ binding to annexin 2 (a phospholipid and $\mathrm{Ca}^{2+}$ binding protein) allows for interaction with membranes. Thus, S100A10annexin 2 can link proteins to membranes or attach to and modulate other proteins. Interestingly, the protein predominantly binds to the plasma membrane where it interacts for example with phosphatidylinositol-bisphosphate $\left(\mathrm{PI}(4,5) \mathrm{P}_{2}\right)$ or cholesterol-rich domains (Rescher et al., 2004). S100A10-annexin 2 has been identified as auxiliary protein in epithelial $\mathrm{Ca}^{2+}$ permeant TRPV5 and TRPV6 channels (van de Graaf et al., 2003). TRP (transient receptor potential) channels constitute a superfamily of sensory channels whose functions range from phototransduction (where they were first described), olfaction, heat, cold sensation, etc., to $\mathrm{Ca}^{2+}$ sensors/transporters. The TRP Ca ${ }^{2+}$ channels are important for absorption of $\mathrm{Ca}^{2+}$ into kidney, placenta, or intestine to maintain systemic $\mathrm{Ca}^{2+}$ homeostasis. The S100A10-annexin 2 complex specifically associates with the C-terminal of TRP channels and is suggested to play a role in guiding and localizing channels to the plasma membrane and/or in the modulation of channel activity. The later has been shown by using annexin 2 interfering RNA, which inhibited currents through TRP channels (van de Graaf et al., 2003). S100A10-annexin 2 is also involved in nociceptive function. It appears to act as scaffolding protein that conjugates appropriate proteins at the plasma membrane. Deletion of the proteins exclusively from nociceptive sensory neurons in mice was attended by a loss of TTX-resistant $\mathrm{Na}^{+}\left(\mathrm{Na}_{\mathrm{v}} 1.8\right)$ channels and compromised neuropathic pain behavior (Foulkes et al., 2006).

S100A10-annexin 2 also interacts with acid-sensing ion channels (ASIC1a; Donier et al., 2005). Coexpression of S100A10annexin 2 and the ASIC1a channels led to an increased expression of ion channels at the plasma membrane and a concommitant increase of the peak current. Since no other parameters 
were affected it was suggested that the primary role of S100A10annexin 2 is to enhance the expression of the acid-sensing channels in the plasma membrane, which supports the notion of S100A10-annexin 2 functioning as trafficking device.

S100B and likely S100A1 interact with and stimulate rod outer segment and photoreceptor bipolar cell synapse membrane guanylate cyclase (ROS-GC1), which is a bimodal $\mathrm{Ca}^{2+}$ signal transduction switch that increases its rate of cyclic GMP synthesis when intracellular $\mathrm{Ca}^{2+}$ rises to high levels and when $\mathrm{Ca}^{2+}$ falls to very low levels (Pozdnyakov et al., 1997; Rambotti et al., 1999; Duda et al., 2002). S100B and likely S100A1 stimulate photoreceptor ROS-GC1 activity as $\mathrm{Ca}^{2+}$ approaches micromolar levels, i.e., when photoreceptors are dark adapted, implying that S100B and likely S100A1 are important in dark adaptation. Thus, S100B and S100A1 indirectly regulate a photoreceptor $\mathrm{Ca}^{2+}$ channel via stimulation of ROS-GC1. However, S100B and S100A1 also activate a membrane bound guanylate cyclase in retinal Müller cells (Rambotti et al., 1999), and S100B stimulates a membrane bound guanylate cyclase in the photoreceptor bipolar synapse (Duda et al., 2002), which suggests that at those sites also at least S100B might indirectly regulate $\mathrm{Ca}^{2+}$ flux via activation of a membrane bound guanylate cyclase.

S100A1 and S100B each promote $\mathrm{Ca}^{2+}$ flux across artificial membranes (Garbuglia et al., 2000) as do annexins 5 and 6 (Gerke and Moss, 2002). S100A1 and S100B interact with annexins 5 and 6 which results in reduced ability of these two annexins and of S100A1 and S100B to stimulate $\mathrm{Ca}^{2+}$ flux across artificial membranes likely via reciprocal sequestration within the cytoplasm (Garbuglia et al., 2000). These four proteins are located close to or on skeletal muscle membrane structures such as the sarcolemma, the sarcoplasmic reticulum, and T-tubules (Arcuri et al., 2002) that are critically involved in the regulation of $\mathrm{Ca}^{2+}$ fluxes. This suggests that S100A1 and S100B might modulate the proposed $\mathrm{Ca}^{2+}$ channel activity of annexins 5 and 6 and/or annexin 6-dependent regulation of $\mathrm{Ca}^{2+}$ release from the sarcoplasmic reticulum (Díaz-Muñoz et al., 1990).

Signaling via ion channels appears to be also involved in regulation of S100B secretion. Hippocampal brain slices in the absence of extracellular $\mathrm{Ca}^{2+}$ or low $\mathrm{K}^{+}$caused an increase of $\mathrm{S} 100 \mathrm{~B}$ secretion (probably by internal $\mathrm{Ca}^{2+}$ liberation which is a common mechanism in glial cells), whereas high extracellular $\mathrm{K}^{+}$or $\mathrm{Ca}^{2+}$ channel blockers had the opposite effect (Nardin et al., 2009). This may be relevant during/after neuronal activity, particularly after excessive excitation such as in epileptic seizure, where within a small interstitial volume around cells ion concentrations may change significantly.

S100A1 binds to ryanodine receptors at nanomolar $\mathrm{Ca}^{2+}$ concentrations and enhances $\mathrm{Ca}^{2+}$ release in skeletal and in cardiac muscle (Treves et al., 1997; Prosser et al., 2008; Wright et al., 2008). Ryanodine receptors are L-type $\mathrm{Ca}^{2+}$ channels located in the SR, which after opening allow $\mathrm{Ca}^{2+}$ ions to flow down their electrochemical gradient from the higher concentration with the SR to the lower concentrated cytoplasm. S100A1 increased the open probability of the ryanodine $\mathrm{Ca}^{2+}$ channels reconstituted into planar lipid bilayers (Treves et al., 1997). S100A1, after binding of $\mathrm{Ca}^{2+}$ exposes hydrophobic pockets and competes with calmodulin for the same binding site, which is conserved in striated muscle (Schäfer and Heizmann, 1996). S100A1 knock-out mice exhibit decreased action potential evoked $\mathrm{Ca}^{2+}$ release via SR ryanodine receptors (Prosser et al., 2010). From these experiments it appears that intracellular S100A1 regulates $\mathrm{Ca}^{2+}$ channels that subsequently promote muscle contractility. The authors further examined the effect of S100A1 on the voltage sensor of excitationcontraction coupling (Prosser et al., 2009a,b). Depolarization of the transverse $(\mathrm{T})$ tubulus system by action potentials that spread over the muscle sarcolemma acts at the voltage sensor of the ruthenium/calcium receptor/channel. The conformational changes of the protein mechanically transmit to dihydropyridine receptors, which are also L-type $\mathrm{Ca}^{2+}$ channels, located in the SR membrane. Charge movement within these channels is responsible for opening and release of $\mathrm{Ca}^{2+}$ from the SR. Part of the charge movement, the so called "delayed charge movement" (termed Qgamma), is selectively suppressed in S100A1 knock-out muscle fibers. Both, skeletal and cardiac ryanodine receptors are regulated this way by S100A1. The $\mathrm{Q}_{\text {gamma }}$ component activated by S100A1, however, appears not to be linked to gating of dihydropyridine $\mathrm{Ca}^{2+}$ channels, but is more likely involved in the excitation-contraction coupling machinery (Prosser et al., 2009a). S100A1 also improves $\mathrm{Ca}^{2+}$ cycling and contractility in cardiac muscle (Most et al., 2007) and increased $\mathrm{Ca}^{2+}$ release and force of contraction in skinned muscle fibers (Most et al., 2003).

Cardiomyocytes secrete S100A1 during ischemia which is taken up by superior cervical ganglion (SCG) neurons (which do not contain the protein) and distribute the protein intracellularly via axonal transport (Hernández-Ochoa et al., 2009). Extra- or intracellularly applied S100A1 enhanced voltage activated $\mathrm{Ca}^{2+}$ channels dependent on PKA activity, prolonged action potentials, and augmented transient cytosolic $\mathrm{Ca}^{2+}$ increase. S100A1 was shown to directly interact with PKA and this complex appears to affect $\mathrm{Ca}^{2+}$ channels. S100A1 therefore appears to act as a signaling molecule that increases sympathetic output.

\section{S100s AND $\mathrm{K}^{+}$CHANNELS}

$\mathrm{K}^{+}$channels are the most abundant and versatile kind of channel ubiquitously present in cells. $\mathrm{K}^{+}$channels once activated allow $\mathrm{K}^{+}$ions to move down their electrochemical gradient, which is usually from inside (high concentration and negative membrane potential) to the external side of the plasma membrane. Since the equilibrium potential $\left(\mathrm{E}_{\mathrm{K}}\right)$ for $\mathrm{K}^{+}$is negative $\left(\mathrm{E}_{\mathrm{K}} \sim-60\right.$ to $-90 \mathrm{mV}$ in nerve and glial cells), opening of $\mathrm{K}^{+}$channels drives the membrane potential toward the equilibrium for $\mathrm{K}^{+}$and causes hyperpolarization of cells. $\mathrm{K}^{+}$channels are therefore involved in establishing and maintenance of the membrane resting potential, in repolarization of action potentials, or in membrane potential oscillations. In essence $\mathrm{K}^{+}$channels provide a negative feedback to adjust the excitability of cells.

The many types of $\mathrm{K}^{+}$channels are classified into three major families depending on their number of transmembrane segments/helices (TMS). Formation of a functional channel involves the assembly of two to four units, depending on the number of TMSs in each family. The simplest $\mathrm{K}^{+}$channel is the four times two helix set, each containing a pore loop $(\mathrm{P})$ and together forming the channel - the so called "inward rectifier," $K_{\text {ir }}$ (2TMS/1P) channel. Doubling of this basic structure yields four helices each 
containing two pore loops. Dimerization in the membrane provides four pore loops which form a channel - the so called "twopore domain $\mathrm{K}^{+}$channels" $\left(\mathrm{K}_{2 \mathrm{P}}\right.$ or $\left.4 \mathrm{TMS} / 2 \mathrm{P}\right)$. These channels are highly sensitive and modulated by external $\mathrm{pH}$, by neurotransmitters and hormones and are a target of volatile anesthetics (review Lotshaw, 2007; Mathie et al., 2010). These types of channels contribute to the membrane resting potential and are involved in modulating electrical activity of cells. The "voltagedependent $\mathrm{K}^{+}$channels" consist of 6 TMS containing 1 pore loop (6TMS/1P) each and on tetramerisation in the membrane assemble to one $\mathrm{K}^{+}$channel (Armstrong, 2003). A variation of this channel type has 7 transmembrane segments (7-TMS) and a long C-terminus that provides binding of $\mathrm{Ca}^{2+}$ ions - these channels therefore have been termed " $\mathrm{Ca}^{2+}$ activated $\mathrm{K}^{+}$channels" (for recent reviews see Berkefeld et al., 2010; Lee and Cui, 2010; Wu et al., 2010).

$\mathrm{Ca}^{2+}$ activated $\mathrm{K}^{+}$channels are divided into three subfamilies mainly defined by their biophysical and pharmacological properties. (a) Three types of "small K or SK channels" identified have a single channel conductance $(\gamma)$ of $\sim 10 \mathrm{pS}$, are voltage independent, associated with the EF-hand $\mathrm{Ca}^{2+}$-binding protein calmodulin, activated by $\mathrm{Ca}^{2+}$ binding to calmodulin, and some are specifically blocked by the bee toxin apamin. (b) "Intermediate K or IK channels," which have a $\gamma$ of $20-80$ pS, are constitutively associated with calmodulin, which is bound to the C-terminal of the protein and confers $\mathrm{Ca}^{2+}$ sensitivity to the channels. These channels have no or only weak voltage dependence and are blocked by charybdotoxin (from scorpion) but are resistant to blockade by apamin or iberiotoxin (scorpion toxin). (c) "Big (large or maxi) conductance $\mathrm{K}^{+}$channels (big K, BK)" with a $\gamma$ of 100 $300 \mathrm{pS}$ are activated by $\mathrm{Ca}^{2+} / \mathrm{Mg}^{2+}$ ions and membrane voltage synergistically. These channels are specifically blocked by iberiotoxin and modulated by a great variety of compounds such as ethanol, polyamines, or gasotransmitters (Weiger and Hermann, 1994, 2009; Jakab et al., 1997; Hermann et al., 2012). The various types of SK, IK, or BK channels can be expressed alone or in combination in many cells and tissues, as in the nervous or the vascular system. These types of $\mathrm{K}^{+}$channels are involved in action potential repolarization, modulation of action potential frequency, or oscillatory electrical discharge activity.

In some $\mathrm{Ca}^{2+}$ activated $\mathrm{K}^{+}$channels calmodulin exerts important functions as $\mathrm{Ca}^{2+}$ sensor at the internal side as outlined above. Since certain S100 proteins are able to compete with calmodulin (Schäfer and Heizmann, 1996), this allows them to interact with ion channels via this pathway. $\mathrm{Ca}^{2+}$ activated $\mathrm{BK}$ channels typically contain $\mathrm{Ca}^{2+}$ binding sites (of non EF-hand type) at their $\mathrm{C}$-terminal end. There is some indication that $\mathrm{Ca}^{2+}$ activated $\mathrm{K}^{+}$ conductance of invertebrate neurons is increased by S100 proteins (Kubista et al., 1999). It should be noted that various S100 proteins (A1, A6, A8, A9, A10, A13, and B) are enriched in cochlea, which also expresses BK channels (Pyott et al., 2007). S100 proteins have, however, not been yet reported being involved in activation or modulation of these channels.

In Alzheimer's disease a correlation between a loss of inward rectifier $\mathrm{K}^{+}$channels $\left(\mathrm{K}_{\mathrm{ir}} 4.1\right.$ ), BK channels, water channels (aquaporin 4), and a gain of S100B-positive astrocytes was found (Wilcock et al., 2009). This has been attributed to a loss of a common anchoring protein. Efflux of $\mathrm{K}^{+}$ions via BK channels at the astrocyte end feet results in vasodilation, which suggests an important function of these channels in maintainance of vascular tone (Filosa et al., 2006). The correlation to S100B, however, remains elusive.

S100A10-annexin 2 interacts specifically with one of the twopore domain $\mathrm{K}^{+}$channels $\left(\mathrm{K}_{2 \mathrm{P}}\right)$ - termed "TASK-1 channels" (Girard et al., 2002). TASK channels (TWIK-related Acid Sensitive $\mathrm{K}^{+}$channels) are characterized by the absence of activation and inactivation kinetics, hence are voltage independent and therefore are referred to as leak or background conductances involved in setting the membrane resting potential. The channels sense external $\mathrm{H}^{+}$around the physiological $\mathrm{pH}$ and are inhibited by hormones and neurotransmitters (Lotshaw, 2007). The association with S100A10-annexin 2 is essential for TASK-1 channel trafficking to the plasma membrane and hence for functionality. The authors found that association requires the presence of a serineserine-valine (SSV) amino acid sequence in the C-terminus of the channel. Another sequence - lysine-arginine-arginine (KRR) just upstream of the SSV sequence - appeared as retention signal which makes TASK channels to reside within the endoplasmic reticulum. It has been suggested that only after camouflaging the KRR sequence by binding of S100A10-annexin 2 the channels can move to the plasma membrane (Girard et al., 2002).

S100A10-annexin 2 also regulates trafficking of the TTXresistant $\mathrm{Na}^{+}$channels to the plasma membrane. However, these channels do neither contain a SSV terminal sequence nor a KRR motif but appear to exhibit similar motifs. Using different techniques other authors found that S100A10-annexin 2 is localized to a more distant site to the C-terminal end of TASK-1 and binding of S100A10-annexin 2 to TASK-1 may represent the retention factor that causes channels to remain in the ER hence retarding plasma membrane expression of the channels (Renigunta et al., 2006).

$\mathrm{S} 100 \mathrm{~B}$ inhibits voltage-dependent and $\mathrm{Ca}^{2+}$ sensitive human ether a go-go (hEAG1) $\mathrm{K}^{+}$channels - a S1-S6 TMS containing 1 pore loop (6TMS/1P) type channel (Sahoo et al., 2010). These $\mathrm{K}^{+}$channels are ubiquitously expressed in neuronal tissue and appear to play a role in tumor proliferation and progression. When applied to the internal face of inside-out patches, S100B caused a $\mathrm{Ca}^{2+}$-dependent block of the channels. S100B was further shown to share the same binding sites with calmodulin and hence was suggested to function as an alternative $\mathrm{Ca}^{2+}$ sensor for these channels (Sahoo et al., 2010).

\section{S100s AND $\mathrm{Cl}^{-}$CHANNELS}

$\mathrm{Cl}^{-}$channels are found in various non-excitable cells, being involved in volume and $\mathrm{pH}$ regulation, cell proliferation, or $\mathrm{Ca}^{2+}$ signaling (Suzuki et al., 2006). $\mathrm{Cl}^{-}$channels contain 10 or 12 transmembrane helices but bear no resemblance to cation channels. Functionally, these channels are involved in setting the resting membrane potential of skeletal muscle, in solute transport, in $\mathrm{pH}$ and volume regulation, in cell migration, cell proliferation, and differentiation. The S100A10-annexin 2 complex was reported to directly or indirectly activate mechano-/volume-sensitive $\mathrm{Cl}^{-}$ channels in endothelial cells (Nilius et al., 1996). S100A10-annexin 2 also relates to the functioning of the cystic fibrosis transmembrane conductance (CFTR) under normal and pathologic 
Table 1 | Interactions of $\mathbf{S} 100$ proteins with ion channels ${ }^{\mathbf{1}}$.

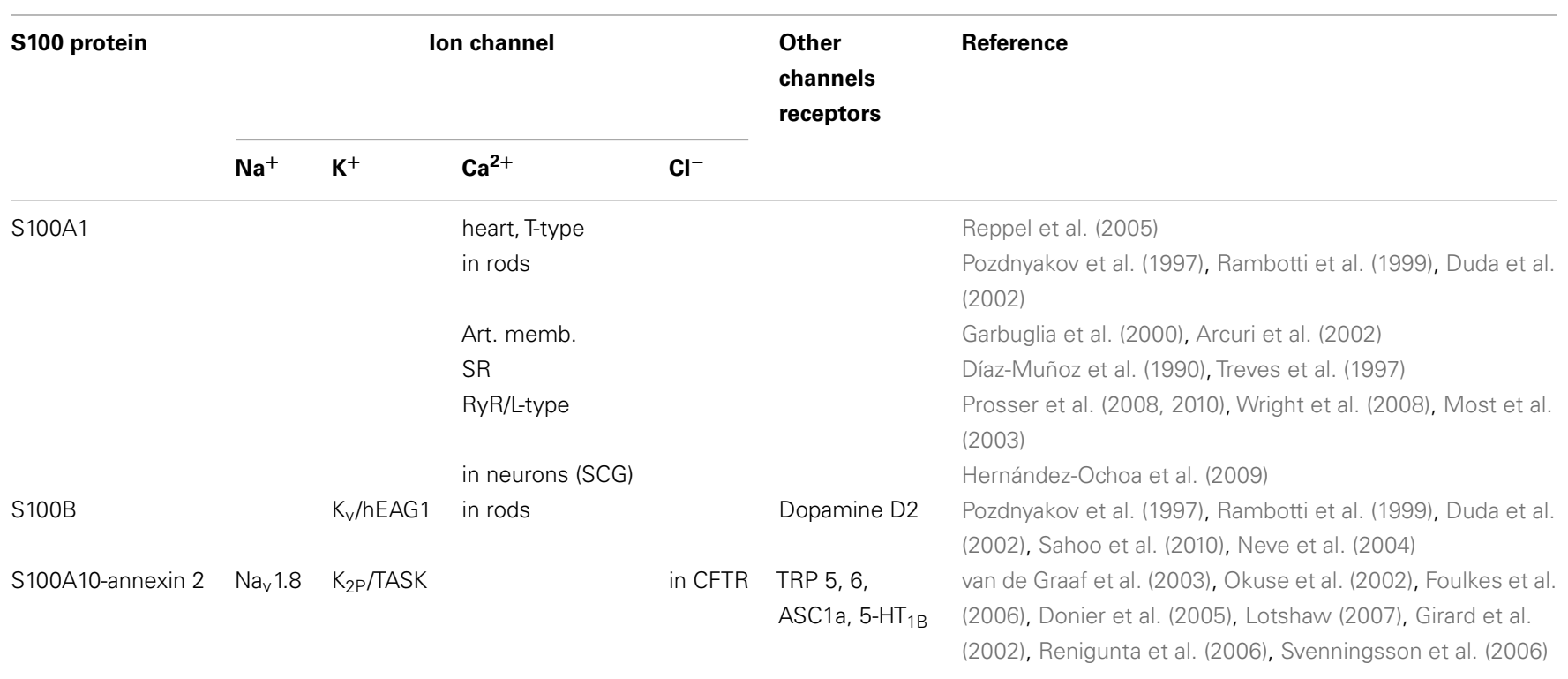

${ }^{1}$ Abbreviations: Art. memb., Artificial membrane; ASC, acid-sensing ion channel; CFTR, cystic fibrosis transmembrane conductance; $h E A G$, human ether a go-go $K^{+}$ channel; $5-H T_{1 B}$, serotonin receptor; $K_{2 p}$, two-pore domain $K^{+}$channel; $K_{v}$, voltage gated $K^{+}$channel; $\mathrm{Na}_{v}$, voltage gated $\mathrm{Na}^{+}$channel; $R$ R $R$, ryanodine receptor; SCG, superior cervical ganglion; SR, sarcoplasmatic reticulum; TASK, TWIK-related Acid Sensitive $K^{+}$channel; TRP transient receptor potential.

conditions (Muimo, 2009). Mutations at this protein lead to an impairment of salt and water transport across respiratory, digestive, and reproductive epithelia causing excessive mucous accumulation and/or tissue fibrosis. The S100A10-annexin 2 complex is regulated in these tissues by a cyclic adenosine monophosphate (cAMP)/PKA/calcineurin A $(\mathrm{CnA})$ - protein phosphatase and interacts with CFTR. Inhibition of CnA disrupts complex formation and attenuates CFTR function. Thus only the multiprotein complex associated with S100A10-annexin 2 in its assembled form is able to open CFTR $\mathrm{Cl}^{-}$channels within the cell surface membrane (Borthwick et al., 2007, 2008). In summary, the S100A10-annexin 2 complex is well suited for regulation of membrane receptors and ion channels with annexin providing the attachment to the membrane bilayer and S100A10 providing the link to receptor, ion channel, or cytoskeletal proteins. In some cases the binding motifs for S100A10-annexin 2 are not resolved, as in TTX-resistant $\mathrm{Na}^{+}$or in CFTR channels.

\section{S100s AND LIGAND ACTIVATED CHANNELS}

S100B also interacts with and modulates ligand activated channels such as dopamine D2 metabotropic receptors (Liu et al., 2008). Mutations at the dopaminergic system are linked to Parkinson's disease, schizophrenia, or drug addiction (Beaulieu and Gainetdinov, 2011). The dopamine D2 receptor is a 7-TMS receptor that acts via $\mathrm{G}$-proteins $\mathrm{G} \alpha_{i}$ and $\mathrm{G} \alpha_{\mathrm{o}}$ inhibiting adenylyl cyclase (AC), $\mathrm{K}^{+}$channels, or the mitogen-activated protein kinase (MAPK; Neve et al., 2004). S100B appears to bind to the D2 receptor's third cytoplasmic loop at the amino acid terminus and this way enhances receptor signaling. The third cytoplasmic loop is also prominent as a contact site for G-protein coupling as well as for binding of calmodulin (Liu et al., 2007). Also the metabotropic serotonin $1 \mathrm{~B}$ receptor $\left(5-\mathrm{HT}_{1 \mathrm{~B}}\right)$ has been found to interact with S100A10-annexin 2 causing an increased localization of the receptors to the plasma membrane (Svenningsson et al., 2006). S100A10-annexin 2 was decreased during depression attacks or depression-like states in knock-out animals but was increased after antidepressant therapy or overexpression. Interactions of S100 proteins with ion channels are summarized in Table 1 .

\section{RELATIONSHIP TO CALMODULIN - ION CHANNEL INTERACTIONS}

It is likely that certain S100 proteins modulate the activity of ion channels by competing with calmodulin for target binding sites (Schäfer and Heizmann, 1996). Hence, some ion channels that are regulated by calmodulin may in fact be modulated by S100 proteins, either under resting conditions or under special circumstances. Whether the effect of S100 proteins is direct or indirect, knowledge of the molecular basis for calmodulin interactions with ion channels may be helpful in discerning how $\mathrm{S100}$ proteins modulate ion channels, in particular since there may well be a similarity in their mode of action. Progress has been made in understanding the molecular basis for calmodulin modulation of voltage activated $\mathrm{Ca}^{2+}$ and $\mathrm{Na}^{2+}$ channels (Shah et al., 2006a). The mechanism for $\mathrm{Ca}^{2+}$-dependent regulation of voltage gated $\mathrm{Na}^{+}$channels $(\mathrm{Na} V)$ is particularly complex, with involvement of calmodulin, a $\mathrm{Ca}^{2+}$ binding EF-hand domain in the C-terminal cytoplasmic domain (Wingo et al., 2004) and a calmodulin binding IQ motif just downstream the EF-hand domain (Shah et al., 2006b). These two $\mathrm{Ca}^{2+}$ sensors mutually influence each other and modulate the fast inactivation gate in the D3-D4 linker domain (Potet et al., 2009; Sarhan et al., 2009). The physiological relevance of $\mathrm{Ca}^{2+}$ regulation of $\mathrm{Nav}$ channels is underscored by mutations in the $\mathrm{Ca}^{2+}$ regulatory apparatus being associated with a variety 
of heart arrhythmia syndromes. In tetrodotoxin-insensitive $\mathrm{Na}^{+}$ channels $\left(\mathrm{Na}_{\mathrm{v}} 1.8\right)$ S100A10-annexin 2 binds to the N-terminus and promotes their translocation to the plasma membrane producing functional channels (Okuse et al., 2002). Increased $\mathrm{Na}_{\mathrm{v}} 1.8$ activity has been proposed to cause hyperexcitability of sensory neurons, a mechanism that renders nociceptors more sensitive. Whether S100s also play a role in this context in genuine $\mathrm{Na}^{+}$ channels remains to be investigated.

\section{S100 PROTEINS IN NON-VERTEBRATE ORGANISMS?}

Sequence comparisons of the genomes of yeast, Caenorhabditis elegans, and Drosophila revealed no typical S100 genes in these species (Heizmann et al., 2002). The EF-hand CaBP family is well conserved as the motif is even found in bacteria. The inability to recognize S100 proteins in non-vertebrate species may arise because the features of the invertebrate protein sequence deviate from the basic form and therefore cannot be recognized by traditional sequence search algorithms. Also, key to identifying S100 proteins is the unique 14 -amino acid, $\mathrm{S} 100$-specific $\mathrm{Ca}^{2+}$ binding loop in their N-terminal binding site. These key sites may be difficult to identify due to the conservation of only the Glu residue in position 14. Although the S100-specific loop is unique, it is in fact not the most distinguishing characteristic of S100 proteins. Rather, it is their integrated dimeric structural unit that makes S100 proteins different from all other EF-hand CaBPs. Since there is no current method to recognize dimeric proteins based on protein sequence, one cannot completely rule out that S100 proteins are not present in non-vertebrate organisms.

This line of reasoning also suggests that the use of vertebrate S100 antibodies to identify S100 in invertebrates is questionable. The antibodies to invertebrate $\mathrm{S} 100$ proteins may need to recognize a different epitope that has no sequence resemblance to vertebrate

\section{REFERENCES}

Andrianov, V. V., Gainutdinov, K. L., Gainutdinova, T. K., Mukhamedshina, D. I., Shtark, M. B., and Epstein, O. I. (2003). Membranotropic effects of antibodies to $\mathrm{S} 100$ protein in ultralow doses. Bull. Exp. Biol. Med. 135(Suppl. 7), 114-116.

Arcuri, C., Bianchi, R., Brozzi, F., and Donato, R. (2005). S100B increases proliferation in PC12 neuronal cells and reduces their responsiveness to nerve growth factor via Akt activation. J. Biol. Chem. 280, 4402-4414.

Arcuri, C., Giambanco, I., Bianchi, R., and Donato, R. (2002). Annexin V, annexin VI, S100A1 and S100B in developing and adult avian skeletal muscles. Neuroscience 109, 371-388.

Armstrong, C. M. (2003). Voltage-gated K channels. Sci. STKE 2003, re10.

Ashcroft, F. M. (2006). From molecule to malady. Nature 440, 440-447.

Averill, M. M., Barnhart, S., Becker, L., Li, X., Heinecke, J. W., Leboeuf, R. C., Hamerman, J. A., Sorg, C.,

S100 proteins. Further studies are necessary to obtain and analyze more sequence and structural information from a range of species to investigate the evolution of this protein family in more detail (Heizmann et al., 2002), and to possibly identify the presence or absence of a S100-like protein in invertebrates. Even if S100-like $\mathrm{CaBPs}$ can not be recognized in invertebrates, $\mathrm{S} 100$ proteins can clearly affect their electrical discharge activity and alter membrane conductances. Thus, $\mathrm{S} 100$ proteins from a vertebrate host have the potential to interact with binding sites on channels or to modulate intracellular signaling to an extent that channel gating is affected in an invading non-vertebrate organism.

\section{CONCLUDING REMARKS}

S100 EF-hand proteins exhibit a remarkably diverse range of cellular functions. Accumulating evidence indicates that they can modulate the activities of ion channels. We hypothesize that various ion channels, in particular $\mathrm{K}^{+}$channels, exhibit intracellular binding sites for several $\mathrm{S} 100$ proteins, which serve as $\mathrm{Ca}^{2+}$ sensor to modulate their electrical behavior. These binding sites may correspond to known sites for the ubiquitous EF-hand $\mathrm{Ca}^{2+}$ sensor calmodulin, but might also be distinct. The potential for overlap complicates efforts to assign specific biological functions to S100 proteins. Given the differences in the structural basis for target activation by monomeric calmodulin versus oligomeric S100 proteins, it is conceivable that the effects of $S 100$ proteins will be distinct from those of calmodulin. Further biochemical, structural, and functional studies are required to elucidate the physiological role(s) of S100 protein in modulating the function of ion channels.

\section{ACKNOWLEDGMENTS}

S100 protein research in the Chazin lab has been supported by the US National Institutes of Health, currently through grant (R56 AI91771).

protein and RAGE. Age (Dordr.) 33, 523-541.

Berkefeld, H., Fakler, B., and Schulte, U. (2010). $\mathrm{Ca}^{2+}$-activated $\mathrm{K}^{+}$ channels: from protein complexes to function. Physiol. Rev. 90, 1437-1459.

Bernard, G., and Shevell, M. I. (2008). Channelopathies: a review. Pediatr. Neurol. 38, 73-85.

Bhattacharya, S., Bunick, C. G., and Chazin, W. J. (2004). Target selectivity in EF-hand calcium binding proteins. Biochim. Biophys. Acta 1742, 69-79.

Bode, G., Lüken, A., Kerkhoff, C., Roth, J., Ludwig, S., and Nacken, W. (2008). Interaction between S100A8/A9 and annexin A6 is involved in the calciuminduced cell surface exposition of S100A8/A9. J. Biol. Chem. 283, 31776-31784.

Borthwick, L. A., McGaw, J., Conner, G., Taylor, C. J., Gerke, V., Mehta, A., Robson, L., and Muimo, R. (2007). The formation of the cAMP/protein kinase A-dependent annexin 2-S100A10 complex with cystic fibrosis conductance regulator protein (CFTR) regulates CFTR channel function. Mol. Biol. Cell 18, 3388-3397.

Borthwick, L. A., Riemen, C., Goddard, C., Colledge, W. H., Mehta, A., Gerke, V., and Muimo, R. (2008). Defective formation of PKA/CnA-dependent annexin 2-S100A10/CFTR complex in DeltaF508 cystic fibrosis cells. Cell. Signal. 20, 1073-1083.

Brozzi, F., Arcuri, C., Giambanco, I., and Donato, R. (2009). S100B protein regulates astrocyte shape and migration via interaction with Src kinase: implications for astrocyte development, activation, and tumor growth. J. Biol. Chem. 284, 8797-8811.

Burgoyne, R. D., and Weiss, J. L. (2001). The neuronal calcium sensor family of $\mathrm{Ca}^{2+}$-binding proteins. Biochem. J. 353, 1-12.

Celio, M. R. (1986). Parvalbumin in most gamma-aminobutyric acid-containing neurons of the rat cerebral cortex. Science 231, 995-997. 
Chazin, W. J. (2011). Relating form and function of EF-hand calcium binding proteins. Acc. Chem. Res. 44, 171-179.

Chen, M., Sinha, M., Luxon, B. A., Bresnick, A. R., and O'Connor, K. L. (2009). Integrin alpha6beta4 controls the expression of genes associated with cell motility, invasion, and metastasis, including S100A4/metastasin. J. Biol. Chem. 284, 1484-1494.

Cheng, P., Corzo, C. A., Luetteke, N., Yu, B., Nagaraj, S., Bui, M. M., Ortiz, M., Nacken, W., Sorg, C., Vogl, T., Roth, J., and Gabrilovich, D. I. (2008). Inhibition of dendritic cell differentiation and accumulation of myeloid-derived suppressor cells in cancer is regulated by S100A9 protein. J. Exp. Med. 205, 2235-2249.

Curatola, G., Mazzanti, L., Ferretti, G., and Donato, R. (1985). S100 protein-induced changes in the physical state of synaptosomal particulate fractions as monitored by spin labels. Arch. Biochem. Biophys. 240, 435-445.

Díaz-Muñoz, M., Hamilton, S. L., Kaetzel, M. A., Hazarika, P., and Dedman, J. R. (1990). Modulation of $\mathrm{Ca}^{2+}$ release channel activity from sarcoplasmic reticulum by annexin VI (67-kDa calcimedin). J. Biol. Chem. 265, 15894-15899.

Donato, R. (2001). S100: a multigenic family of calcium-modulated proteins of the EF-hand type with intracellular and extracellular functional roles. Int. J. Biochem. Cell Biol. 33, 637-668.

Donato, R. (2003). Intracellular and extracellular roles of $\mathrm{S} 100$ proteins. Microsc. Res. Tech. 60, 540-551.

Donato, R. (2007). RAGE: a single receptor for several ligands and different cellular responses: the case of certain $\mathrm{S} 100$ proteins. Curr. Mol. Med. 7, 711-724.

Donato, R., Sorci, G., Riuzzi, F., Arcuri, C., Bianchi, R., Brozzi, F., Tubaro, C., and Giambanco, I. (2009). S100B's double life: intracellular regulator and extracellular signal. Biochim. Biophys. Acta 1793, 1008-1022.

Donier, E., Rugiero, F., Okuse, K., and Wood, J. N. (2005). Annexin II light chain $\mathrm{p} 11$ promotes functional expression of acid-sensing ion channel ASICla. J. Biol. Chem. 280, 38666-38672.

Duda, T., Koch, K.-W., Venkataraman, V., Lange, C., Beyermann, M., and Sharma, R. K. (2002). Ca(2+) sensor S100beta-modulated sites of membrane guanylate cyclase in the photoreceptor-bipolar synapse. EMBO J. 21, 2547-2556.
Eggers, K., Sikora, K., Lorenz, M., Taubert, T., Moobed, M., Baumann, G., Stangl, K., and Stangl, V. (2011). RAGE-dependent regulation of calcium-binding proteins S100A8 and S100A9 in human THP1. Exp. Clin. Endocrinol. Diabetes 119, 353-357.

Ehrchen, J. M., Sunderkötter, C., Foell, D., Vogl, T., and Roth, J. (2009). The endogenous toll-like receptor 4 agonist S100A8/S100A9 (calprotectin) as innate amplifier of infection, autoimmunity, and cancer. $J$. Leukoc. Biol. 86, 557-566.

Emberley, E. D., Niu, Y., Curtis, L., Troup, S., Mandal, S. K., Myers, J. N., Gibson, S. B., Murphy, L. C., and Watson, P. H. (2005). The S100A7-cJun activation domain binding protein 1 pathway enhances prosurvival pathways in breast cancer. Cancer Res. 65, 5696-5702.

Endo, Y., and Endo, T. (1988). Immunohistochemical demonstration of S100 protein in the brain neurosecretory cells of invertebrates (insects and earthworms). Neurosci. Lett. 90, 11-14.

Filosa, J. A., Bonev, A. D., Straub, S. V., Meredith, A. L., Wilkerson, M. K., Aldrich, R. W., and Nelson, M. T. (2006). Local potassium signaling couples neuronal activity to vasodilation in the brain. Nat. Neurosci. 9 , 1397-1403.

Foulkes, T., Nassar, M. A., Lane, T., Matthews, E. A., Baker, M. D., Gerke, V., Okuse, K., Dickenson, A. H., and Wood, J. N. (2006). Deletion of annexin 2 light chain p11 in nociceptors causes deficits in somatosensory coding and pain behavior. $J$. Neurosci. 26, 10499-10507.

Gainutdinov, K. L., Andrianov, V. V., Bergovoy, N. A., Gainutdinova, T. K., Ismailova, A. I., Muranova, L. N., Silantieva, D. I., Stark, M. B., and Epstein, O. I. (2006). Study of effects of antibody to protein S100 on ionic channels of input and output currents of identified neurons of the snail Helix lucorum. J. Evol. Biochem. Physiol. 42, 284-291.

Garbuglia, M., Verzini, M., Hofmann, A., Huber, R., and Donato, R. (2000). S100A1 and S100B interactions with annexins. Biochim. Biophys. Acta 1498, 192-206.

Gerke, V., and Moss, S. E. (2002). Annexins: from structure to function. Physiol. Rev. 82, 331-371.

Ghavami, S., Rashedi, I., Dattilo, B. M., Eshraghi, M., Chazin, W. J., Hashemi, M., Wesselborg, S., Kerkhoff, C., and Los, M. (2008). S100A8/A9 at low concentration promotes tumor cell growth via
RAGE ligation and MAP kinasedependent pathway. J. Leukoc. Biol. 83, 1484-1492.

Gilquin, B., Cannon, B. R., Hubstenberger, A., Moulouel, B., Falk, E., Merle, N., Assard, N., Kieffer, S., Rousseau, D., Wilder, P. T., Weber, D. J., and Baudier, J. (2010) The calcium-dependent interaction between S100B and the mitochondrial AAA ATPase ATAD3A and the role of this complex in the cytoplasmic processing of ATAD3A. Mol. Cell. Biol. 30, 2724-2736.

Girard, C., Tinel, N., Terrenoire, C., Romey, G., Lazdunski, M., and Borsotto, M. (2002). p11, an annexin II subunit, an auxiliary protein associated with the background $\mathrm{K}+$ channel, TASK-1. ЕMBO J. 21, 4439-4448.

Gusev, K., Ackermann, G. E., Heizmann, C. W., and Niggli, E. (2009). $\mathrm{Ca}^{2+}$ signaling in mouse cardiomyocytes with ablated S100A1 protein. Gen Physiol. Biophys. 28, 371-383.

Heizmann, C. W. (2002). The multifunctional S100 protein family. Methods Mol. Biol. 172, 69-80.

Heizmann, C. W., Ackermann, G. E., and Galichet, A. (2007). Pathologies involving the $\mathrm{S} 100$ proteins and RAGE. Subcell. Biochem. 45, 93-138.

Heizmann, C. W., Fritz, G., and Schäfer B. W. (2002). S100 proteins: structure, functions and pathology. Front. Biosci. 7, d1356-d1368.

Hermann, A., and Kerschbaum, $\mathrm{H}$. H. (1994). "Immunohistochemical, biochemical, and physiological characterization of calcium-binding proteins," in Modern Analytical Methods in Histology, eds J. Gu and G. H. Hacker (New York: Plenum Press), 163-185.

Hermann, A., Kubista, H., and Kerschbaum, H. H. (1995). S-100-immunoreactive protein in Helix neurons. Acta. Biol. Hung. 46, 401-411.

Hermann, A., Sitdikova, G. F., and Weiger, T. M. (2012). "BK channels - focus on polyamines, ethanol/acetaldehyde and hydrogen sulfide (H2S)," in Patch Clamp Techniques, ed. F. S. Kaneez, 109-142.

Hernández-Ochoa, E. O., Prosser, B. L., Wright, N. T., Contreras, M., Weber, D. J., and Schneider, M. F. (2009). Augmentation of Cavl channel current and action potential duration after uptake of S100A1 in sympathetic ganglion neurons. Am. J. Physiol. Cell Physiol. 297, C955-C970.

Hille, B. (2001). Ion Channels of Excitable Membranes, 3rd Edn. Sunderland, MA: Sinauer.
Hofmann Bowman, M., Wilk, J., Heydemann, A., Kim, G., Rehman, J., Lodato, J. A., Raman, J., and McNally, E. M. (2010). S100A12 mediates aortic wall remodeling and aortic aneurysm. Circ. Res. 106, 145-154.

Hoppmann, S., Steinbach, J., and Pietzsch, J. (2010). Scavenger receptors are associated with cellular interactions of S100A12 in vitro and in vivo. Int. J. Biochem. Cell Biol. 42, 651-661.

Hsu, K., Champaiboon, C., Guenther, B. D., Sorenson, B. S., Khammanivong, A., Ross, K. F., Geczy, C. L., and Herzberg, M. C. (2009). Anti-infective protective properties of S100 calgranulins. Antiinflamm. Antiallergy Agents Med. Chem. 8, 290-305.

Ismail, T. M., Fernig, D. G., Rudland, P. S., Terry, C. J., Wang, G., and Barraclough, R. (2008). The basic C-terminal amino acids of calcium-binding protein S100A4 promote metastasis. Carcinogenesis 29, 2259-2266.

Jakab, M., Weiger, T. M., and Hermann, A. (1997). Ethanol activates maxi $\mathrm{Ca}^{2+}$-activated $\mathrm{K}^{+}$channels of clonal pituitary (GH3) cells. $J$. Membr. Biol. 157, 237-245.

Kawaguchi, Y., Katsumaru, H., Kosaka, T., Heizmann, C. W., and Hama, K. (1987). Fast spiking cells in rat hippocampus (CA1 region) contain the calcium-binding protein parvalbumin. Brain Res. 416, 369-374.

Klingelhöfer, J., Møller, H. D., Sumer, E. U., Berg, C. H., Poulsen, M. Kiryushko, D., Soroka, V., Ambartsumian, N., Grigorian, M., and Lukanidin, E. M. (2009). Epidermal growth factor receptor ligands as new extracellular targets for the metastasis-promoting S100A4 protein. FEBS J. 276, 5936-5948.

Kubista, H., Donato, R., and Hermann, A. (1999). S100 calcium binding protein affects neuronal electrical discharge activity by modulation of potassium currents. Neuroscience 90 , 493-508.

Kubista, H., Kerschbaum, H. H., and Hermann, A. (1996). S-100immunoreactivity in spontaneously active snail neurons. Brain Res. 716, 53-58.

Kullmann, D. M. (2010). Neurological channelopathies. Annu. Rev. Neurosci. 33, 151-172.

Leclerc, E., Fritz, G., Vetter, S. W., and Heizmann, C. W. (2009). Binding of S100 proteins to RAGE: an update. Biochim. Biophys. Acta 1793, 993-1007.

Lee, U. S., and Cui, J. (2010). BK channel activation: structural and 
functional insights. Trends Neurosci. $33,415-423$.

Levitan, I. B. (1999). Modulation of ion channels by protein phosphorylation. How the brain works. Adv. Second Messenger Phosphoprotein Res. 33, 3-22.

Lim, S. Y., Raftery, M. J., and Geczy, C. L. (2011). Oxidative modifications of DAMPs suppress inflammation: the case for S100A8 and S100A9. Antioxid. Redox Signal. 15, 2235-2248.

Lim, S. Y., Raftery, M. J., Goyette, J., and Geczy, C. L. (2010). S-glutathionylation regulates inflammatory activities of S100A9. J. Biol. Chem. 285, 14377-14388.

Lin, J., Yang, Q., Wilder, P. T., Carrier, F., and Weber, D. J. (2010). The calcium-binding protein $\mathrm{S} 100 \mathrm{~B}$ down-regulates $\mathrm{p} 53$ and apoptosis in malignant melanoma. J. Biol. Chem. 285, 27487-27498.

Liu, Y., Buck, D. C., Macey, T. A., Lan, H., and Neve, K. A. (2007). Evidence that calmodulin binding to the dopamine D2 receptor enhances receptor signaling. J. Recept. Signal Transduct. Res. 27, 47-65.

Liu, Y., Buck, D. C., and Neve, K. A. (2008). Novel interaction of the dopamine D2 receptor and the $\mathrm{Ca} 2+$ binding protein $\mathrm{S100B}$ : role in D2 receptor function. Mol. Pharmacol. 74, 371-378.

Liu, Y., Zhang, R., Xin, J., Sun, Y., Li, J., Wei, D., and Zhao, A. Z. (2011). Identification of S100A16 as a novel adipogenesis promoting factor in 3T3-L1 cells. Endocrinology $152,903-911$.

Lotshaw, D. P. (2007). Biophysical, pharmacological, and functional characteristics of cloned and native mammalian two-pore domain $\mathrm{K}^{+}$ channels. Cell Biochem. Biophys. 47, 209-256.

Malashkevich, V. N., Dulyaninova, N. G., Ramagopal, U. A., Liriano, M. A., Varney, K. M., Knight, D., Brenowitz, M., Weber, D. J., Almo, S. C., and Bresnick, A. R. (2010). Phenothiazines inhibit S100A4 function by inducing protein oligomerization. Proc. Natl. Acad. Sci. U.S.A. 107, 8605-8610.

Malmendal, A., Vander Kooi, C. W., Nielsen, N. C., and Chazin, W. J. (2005). Calcium-modulated S100 protein-phospholipid interactions. An NMR study of calbindin D9k and DPC. Biochemistry 44, 6502-6512.

Marenholz, I., Heizmann, C. W., and Fritz, G. (2004). S100 proteins in mouse and man: from evolution to function and pathology (including an update of the nomenclature). Biochem. Biophys. Res. Commun. 322, 1111-1122.

Mathie, A., Al-Moubarak, E., and Veale, E. L. (2010). Gating of two pore domain potassium channels. J. Physiol. (Lond.) 588, 3149-3156.

Michetti, F., and Cocchia, D. (1982). S100 -like immunoreactivity in a planarian. An immunochemical and immunocytochemical study. Cell Tissue Res. 223, 575-582.

Most, P., Remppis, A., Pleger, S. T., Katus, H. A., and Koch, W. J. (2007). S100A1: a novel inotropic regulator of cardiac performance. Transition from molecular physiology to pathophysiological relevance. Am. J. Physiol. Regul. Integr. Comp. Physiol. 293, R568-R577.

Most, P., Remppis, A., Weber, C., Bernotat, J., Ehlermann, P., Pleger, S. T., Kirsch, W., Weber, M., Uttenweiler, D., Smith, G. L., Katus, H. A., and Fink, R. H. (2003). The C terminus (amino acids 75-94) and the linker region (amino acids 42-54) of the $\mathrm{Ca}^{2+}$-binding protein S100A1 differentially enhance sarcoplasmic $\mathrm{Ca}^{2+}$ release in murine skinned skeletal muscle fibers. J. Biol. Chem. 278, 26356-26364.

Muimo, R. (2009). Regulation of CFTR function by annexin A2-S100A10 complex in health and disease. Gen. Physiol. Biophys. 28, F14-F19.

Nardin, P., Tortorelli, L., QuincozesSantos, A., de Almeida, L. M. V., Leite, M. C., Thomazi, A. P., Gottfried, C., Wofchuk, S. T., Donato, R., and Gonçalves, C.-A. (2009) S100B secretion in acute brain slices: modulation by extracellular levels of $\mathrm{Ca}^{2+}$ and $\mathrm{K}^{+}$. Neurochem. Res. 34 1603-1611.

Neher, E., and Sakaba, T. (2008). Multiple roles of calcium ions in the regulation of neurotransmitter release. Neuron 59, 861-872.

Nejatbakhsh, N., and Feng, Z.-P. (2011). Calcium binding protein-mediated regulation of voltage-gated calcium channels linked to human diseases. Acta Pharmacol. Sin. 32, 741-748.

Neve, K. A., Seamans, J. K., and Trantham-Davidson, H. (2004). Dopamine receptor signaling. $J$. Recept. Signal Transduct. Res. 24, 165-205.

Nikitin, V. P., Lazhetich, B., Baich, M., and Sherstnev, V. V. (1988). Involvement of group S-100 brain specific proteins in the neurophysiological mechanisms of habituation. Neurophysiology 19, 471-478.

Nilius, B., Gerke, V., Prenen, J., Szücs, G., Heinke, S., Weber, K., and Droogmans, G. (1996). Annexin II modulates volume-activated chloride currents in vascular endothelial cells. J. Biol. Chem. 271, 30631-30636

Nishiyama, H., Knopfel, T., Endo, S. and Itohara, S. (2002). Glial protein S100B modulates long-term neuronal synaptic plasticity. Proc. Natl. Acad. Sci. U.S.A. 99, 4037-4042.

Okuse, K., Malik-Hall, M., Baker, M. D., Poon, W.-Y. L., Kong, H., Chao, M. V., and Wood, J. N. (2002). Annexin II light chain regulates sensory neuron-specific sodium channel expression. Nature 417, 653-656.

Pietzsch, J., and Hoppmann, S. (2009). Human S100A12: a novel key player in inflammation? Amino Acids 36, 381-389.

Potet, F., Chagot, B., Anghelescu, M., Viswanathan, P. C., Stepanovic, S. Z., Kupershmidt, S., Chazin, W. J., and Balser, J. R. (2009). Functional interactions between distinct sodium channel cytoplasmic domains through the action of calmodulin. $J$. Biol. Chem. 284, 8846-8854.

Pozdnyakov, N., Goraczniak, R., Margulis, A., Duda, T., Sharma, R. K., Yoshida, A., and Sitaramayya, A. (1997). Structural and functional characterization of retinal calciumdependent guanylate cyclase activator protein (CD-GCAP) identity with S100beta protein. Biochemistry 36, 14159-14166.

Pozdnyakova, A. L. (1988). Comparison of effects of antibodies to S-100 protein and ouabain on Helix pomatia neurons. Bull. Exp. Biol. Med. 106, 1371-1373.

Prosser, B. L., Hernández-Ochoa, E. O., Lovering, R. M., Andronache, Z., Zimmer, D. B., Melzer, W., and Schneider, M. F. (2010). S100A1 promotes action potential-initiated calcium release flux and force production in skeletal muscle. Am. J. Physiol. Cell Physiol. 299, C891-C902.

Prosser, B. L., Hernández-Ochoa, E. O., Zimmer, D. B., and Schneider, M. F. (2009a). The Qgamma component of intra-membrane charge movement is present in mammalian muscle fibres, but suppressed in the absence of S100A1. J. Physiol. (Lond.) 587, 4523-4541.

Prosser, B. L., Hernández-Ochoa, E. O., Zimmer, D. B., and Schneider, M. F. (2009b). Simultaneous recording of intramembrane charge movement components and calcium release in wild-type and S100A1-/- muscle fibres. J. Physiol. (Lond.) 587, 4543-4559.

Prosser, B. L., Wright, N. T., HernãndezOchoa, E. O., Varney, K. M., Liu, Y., Olojo, R. O., Zimmer, D. B., Weber,
D. J., and Schneider, M. F. (2008). S100Al binds to the calmodulinbinding site of ryanodine receptor and modulates skeletal muscle excitation-contraction coupling. $J$. Biol. Chem. 283, 5046-5057.

Pyott, S. J., Meredith, A. L., Fodor, A. A., Vázquez, A. E., Yamoah, E. N., and Aldrich, R. W. (2007). Cochlear function in mice lacking the $\mathrm{BK}$ channel alpha, betal, or beta 4 subunits. J. Biol. Chem. 282, 3312-3324.

Rambotti, M. G., Giambanco, I., Spreca A., and Donato, R. (1999). S100B and S100Al proteins in bovine retina:their calcium-dependent stimulation of a membrane-bound guanylate cyclase activity as investigated by ultracytochemistry. Neuroscience 92, 1089-1101.

Renigunta, V., Yuan, H., Zuzarte, M., Rinné, S., Koch, A., Wischmeyer, E., Schlichthörl, G., Gao, Y., Karschin, A., Jacob, R., Schwappach, B., Daut, J., and Preisig-Müller, R. (2006). The retention factor p11 confers an endoplasmic reticulum-localization signal to the potassium channel TASK-1. Traffic 7, 168-181.

Reppel, M., Sasse, P., Piekorz, R., Tang, M., Roell, W., Duan, Y., Kletke, A. Hescheler, J., Nürnberg, B., and Fleischmann, B. K. (2005). S100A1 enhances the L-type $\mathrm{Ca}^{2+}$ current in embryonic mouse and neonatal rat ventricular cardiomyocytes. $J$. Biol. Chem. 280, 36019-36028.

Rescher, U., and Gerke, V. (2008). S100A10/p11: family, friends and functions. Pflugers Arch. 455, 575-582.

Rescher, U., Ruhe, D., Ludwig, C., Zobiack, N., and Gerke, V. (2004) Annexin 2 is a phosphatidylinositol (4,5)-bisphosphate binding protein recruited to actin assembly sites at cellular membranes. J. Cell Sci. 117, 3473-3480.

Riuzzi, F., Sorci, G., Beccafico, S. and Donato, R. (2012). S100B engages RAGE or bFGF/FGFR1 in myoblasts depending on its own concentration and myoblast density. Implications for muscle regeneration. PLoS ONE 7, e28700. doi:10.1371/journal.pone. 0028700

Riuzzi, F., Sorci, G., and Donato, R. (2011). S100B protein regulates myoblast proliferation and differentiation by activating FGFR1 in a bFGF-dependent manner. J. Cell Sci. 124, 2389-2400.

Rohde, D., Ritterhoff, J., Voelkers, M., Katus, H. A., Parker, T. G., and Most, P. (2010). S100A1: a multifaceted therapeutic target in cardiovascular disease. J. Cardiovasc. Transl. Res. 3 , 525-537. 
Rosenberger, S., Thorey, I. S., Werner, S., and Boukamp, P. (2007). A novel regulator of telomerase. S100A8 mediates differentiation-dependent and calcium-induced inhibition of telomerase activity in the human epidermal keratinocyte line HaCaT. J. Biol. Chem. 282, 6126-6135.

Sahoo, N., Tröger, J., Heinemann, S. H., and Schönherr, R. (2010). Current inhibition of human EAG1 potassium channels by the $\mathrm{Ca} 2+$ binding protein S100B. FEBS Lett. 584, 3896-3900.

Sarhan, M. F., Van Petegem, F., and Ahern, C. A. (2009). A double tyrosine motif in the cardiac sodium channel domain III-IV linker couples calcium-dependent calmodulin binding to inactivation gating. $J$. Biol. Chem. 284, 33265-33274.

Schäfer, B. W., and Heizmann, C. W. (1996). The S100 family of EF-hand calcium-binding proteins: functions and pathology. Trends Biochem. Sci. 21, 134-140.

Schwaller, B. (2010). Cytosolic $\mathrm{Ca}^{2+}$ buffers. Cold Spring Harb. Perspect. Biol. 2, a004051.

Shah, V. N., Chagot, B., and Chazin, W. J. (2006a). Calcium-dependent regulation of ion channels. Calcium Binding Proteins 1, 213-218.

Shah, V. N., Wingo, T. L., Weiss, K. L., Williams, C. K., Balser, J. R., and Chazin, W. J. (2006b). Calciumdependent regulation of the voltagegated sodium channel hH1: intrinsic and extrinsic sensors use a common molecular switch. Proc. Natl. Acad. Sci. U.S.A. 103, 3592-3597.

Shieh, C. C., Coghlan, M., Sullivan, J. P., and Gopalakrishnan, M. (2000). Potassium channels: molecular defects, diseases, and therapeutic opportunities. Pharmacol. Rev. 52, 557-594.

Shtark, M. B., Gainutdinov, K. L., Khichenko, V. I., and Starostina, M. V. (1981). S100, a brain-specific protein: localization and possible role in the snail nervous system. Cell. Mol. Neurobiol. 1, 289-299.

Sorci, G., Bianchi, R., Riuzzi, F., Tubaro, C., Arcuri, C., Giambanco, I., and Donato, R. (2010). S100B protein, a damage-associated molecular pattern protein in the brain and heart, and beyond. Cardiovasc. Psychiatry Neurol. 2010, doi: 10.1155/2010/656481

Sorci, G., Giovannini, G., Riuzzi, F., Bonifazi, P., Zelante, T., Zagarella, S., Bistoni, F., Donato, R., and Romani, L. (2011). The danger signal S100B integrates pathogen- and dangersensing pathways to restrain inflammation. PLoS Pathog. 7, e1001315. doi:10.1371/journal.ppat.1001315
Stein, U., Arlt, F., Walther, W., Smith, J., Waldman, T., Harris, E. D. Mertins, S. D., Heizmann, C. W., Allard, D., Birchmeier, W., Schlag, P. M., and Shoemaker, R. H. (2006). The metastasis-associated gene S100A4 is a novel target of betacatenin/T-cell factor signaling in colon cancer. Gastroenterology 131, 1486-1500.

Steiner, J., Marquardt, N., Pauls, I., Schiltz, K., Rahmoune, H., Bahn, S., Bogerts, B., Schmidt, R. E., and Jacobs, R. (2011). Human CD8 ${ }^{+}$ $\mathrm{T}$ cells and NK cells express and secrete S100B upon stimulation. Brain Behav. Immun. 25, 1233-1241.

Steiner, J., Walter, M., Guest, P., Myint, A. M., Schiltz, K., Panteli, B., Brauner, M., Bernstein, H.-G., Gos, T., Herberth, M., Schroeter, M. L., Schwarz, M. J., Westphal, S., Bahn, S., and Bogerts, B. (2010). Elevated S100B levels in schizophrenia are associated with insulin resistance. Mol. Psychiatry 15, 3-4.

Suzuki, M., Morita, T., and Iwamoto, T. (2006). Diversity of $\mathrm{Cl}(-)$ channels. Cell. Mol. Life Sci. 63, 12-24.

Svenningsson, P., Chergui, K., Rachleff, I., Flajolet, M., Zhang, X., El Yacoubi, M., Vaugeois, J.-M., Nomikos, G. G., and Greengard, P. (2006). Alterations in 5-HT1B receptor function by $\mathrm{p} 11$ in depression-like states. Science 311, 77-80.

Svenningsson, P., and Greengard, P. (2007). p11 (S100A10) - an inducible adaptor protein that modulates neuronal functions. Curr. Opin. Pharmacol. 7, 27-32.

Slomnicki, L. P., Nawrot, B., and Lesniak, W. (2009). S100A6 binds p53 and affects its activity. Int. J. Biochem. Cell Biol. 41, 784-790.

Timoshenko, A. K., Andrianov, V. V., Gainutdinova, T. K., Gainutdinov, K. L., Muranova, L. N., Tagirova, R. R., Shtark, M. B., and Epstein, O. I. (2009). Changes in electrical properties of command neurons during protective effect of low doses of antibodies to $\mathrm{S} 100$ protein on the development of long-term sensitization in Helix lucorum. Bull. Exp. Biol. Med. 148, 598-601.

Treves, S., Scutari, E., Robert, M., Groh, S., Ottolia, M., Prestipino, G., Ronjat, M., and Zorzato, F. (1997). Interaction of S100Al with the $\mathrm{Ca}^{2+}$ release channel (ryanodine receptor) of skeletal muscle. Biochemistry 36, 11496-11503.

Tsoporis, J. N., Marks, A., Haddad, A., Dawood, F., Liu, P. P., and Parker, T. G. (2005). S100B expression modulates left ventricular remodeling after myocardial infarction in mice. Circulation 111, 598-606.
Tubaro, C., Arcuri, C., Giambanco, I., and Donato, R. (2010). S100B protein in myoblasts modulates myogenic differentiation via NF$\kappa \mathrm{B}$-dependent inhibition of MyoD expression. J. Cell. Physiol. 223, 270-282.

Tubaro, C., Arcuri, C., Giambanco, I., and Donato, R. (2011). S100B in myoblasts regulates the transition from activation to quiescence and from quiescence to activation, and reduces apoptosis. Biochim. Biophys. Acta (Mol. Cell. Res.) 1813 1092-1104.

van de Graaf, S. F. J., Hoenderop, J. G. J., Gkika, D., Lamers, D., Prenen, J., Rescher, U., Gerke, V., Staub, O., Nilius, B., and Bindels, R. J. M. (2003). Functional expression of the epithelial $\mathrm{Ca}^{2+}$ channels (TRPV5 and TRPV6) requires association of the S100A10-annexin 2 complex. EMBO J. 22, 1478-1487.

van Dieck, J., Teufel, D. P., Jaulent, A. M., Fernandez-Fernandez, M R., Rutherford, T. J., WyslouchCieszynska, A., and Fersht, A. R. (2009). Posttranslational modifications affect the interaction of S100 proteins with tumor suppressor p53. J. Mol. Biol. 394, 922-930.

Vogl, T., Tenbrock, K., Ludwig, S. Leukert, N., Ehrhardt, C., van Zoelen, M. A. D., Nacken, W. Foell, D., van der Poll, T., Sorg, C., and Roth, J. (2007). Mrp8 and Mrp14 are endogenous activators of Toll-like receptor 4, promoting lethal, endotoxin-induced shock. Nat. Med. 13, 1042-1049.

Weiger, T., and Hermann, A. (1994) Polyamines block $\mathrm{Ca}^{2+}$-activated $\mathrm{K}^{+}$channels in pituitary tumor cells (GH3). J. Membr. Biol. 140, 133-142.

Weiger, T., and Hermann, A. (2009). "Modulation of potassium channels by polyamines," in Biological Aspects of Biogenic Amines Polyamines and Conjugates, ed. G. Dandrifosse (Kerala: Transworld Research Network), 185-199.

Weiger, T. M., Hermann, A., and Levitan. I. B. (2002). Modulation of $\mathrm{Ca}^{2+}$-activated potassium channels. J. Comp. Physiol. A 188, 79-87.

Wilcock, D. M., Vitek, M. P., and Colton, C. A. (2009). Vascular amyloid alters astrocytic water and potassium channels in mouse models and humans with Alzheimer's disease. Neuroscience 159, 1055-1069.

Wingo, T. L., Shah, V. N., Anderson, M. E., Lybrand, T. P., Chazin, W. J., and Balser, J. R. (2004). An EF-hand in the sodium channel couples intracellular calcium to cardiac excitability. Nat. Struct. Mol. Biol. 11, 219-225.
Wolf, R., Ruzicka, T., and Yuspa, S. H. (2011a). Novel S100A7 (psoriasin)/S100A15 (koebnerisin) subfamily: highly homologous but distinct in regulation and function. Amino Acids 41, 789-796.

Wolf, S., Haase-Kohn, C., and Pietzsch, J. (2011b). S100A2 in cancerogenesis: a friend or a foe? Amino Acids 41, 849-861.

Wright, N. T., Prosser, B. L., Varney, K. M., Zimmer, D. B., Schneider, M. F., and Weber, D. J. (2008). S100Al and calmodulin compete for the same binding site on ryanodine receptor. J. Biol. Chem. 283, 26676-26683.

Wu, Y., Yang, Y., Ye, S., and Jiang, Y. (2010). Structure of the gating ring from the human large-conductance $\mathrm{Ca}^{2+}$-gated $\mathrm{K}^{+}$channel. Nature 466, 393-397.

Yan, W. X., Armishaw, C., Goyette, J. Yang, Z., Cai, H., Alewood, P., and Geczy, C. L. (2008). Mast cell and monocyte recruitment by S100A12 and its hinge domain. J. Biol. Chem. 283, 13035-13043.

Zimmer, D. B., and Weber, D. J. (2010). The calcium-dependent Interaction of S100B with its protein targets. Cardiovasc. Psychiatry Neurol. 2010, doi: 10.1155/2010/728052

Zolese, G., Tangorra, A., Curatola, G., Giambanco, I., and Donato, R. (1988). Interaction of S-100b protein with cardiolipin vesicles as monitored by electron spin resonance, pyrene fluorescence and circular dichroism. Cell Calcium 9, 149-157.

Conflict of Interest Statement: The authors declare that the research was conducted in the absence of any commercial or financial relationships that could be construed as a potential conflict of interest.

Received: 06 February 2012; paper pending published: 27 February 2012; accepted: 03 April 2012; published online: 25 April 2012.

Citation: Hermann A, Donato $R$ Weiger TM and Chazin WJ (2012) S100 calcium binding proteins and ion channels. Front. Pharmacol. 3:67. doi: 10.3389/fphar.2012.00067

This article was submitted to Frontiers in Neuropharmacology, a specialty of Frontiers in Pharmacology.

Copyright (c) 2012 Hermann, Donato, Weiger and Chazin. This is an openaccess article distributed under the terms of the Creative Commons Attribution Non Commercial License, which permits non-commercial use, distribution, and reproduction in other forums, provided the original authors and source are credited. 